International Journal of English Literature and Social Sciences
Vol-7, Issue-1; Jan-Feb, 2022
Journal Home Page Available: https://ijels.com/
Journal DOI: $10.22161 /$ ijels

Peer-Reviewed Journal

\title{
Review of Game Theory Applications in International Trade
}

\author{
Chaitanya Khurana
}

Research Assistant, Research and Information system for Developing countries

Received: 07 Dec 2021; Received in revised form: 20 Jan 2022; Accepted: 03 Feb 2022; Available online: 09 Feb 2022

C2022 The Author(s). Published by Infogain Publication. This is an open access article under the CC BY license

(https://creativecommons.org/licenses/by/4.0/).

\begin{abstract}
Game theoretical models have been applied to various fields of economics over the years and has helped in formulating simple models for complex economic scenarios. On such field where these models have been found out to be very useful is the domain of International trade. This paper is a review paper on game theoretical models being applied in international trade for analysing trade wars, trade policy and complex tradenegotiations. The paper also has reviewed game theory models being applied to US China trade war. The paper has tried to review almost every important game theory model which has been useful in finding out optimum results and helping countries make the best policy decisions related to international trade.
\end{abstract}

Keywords-Nash, Equilibrium, Trade, Games, Payoff.

\section{INTRODUCTION}

Globalization has reaped fruits for most of the countries in the world. However, due to globalization the economic dependence on some selected countries has been strong, which gives them an upper-hand while influencing the decisions of the dependent country. Nonetheless, with the financial crisis of 2008 many countries switched over to nationalization and focused on employment and growth of the nation with reducing the importance of globalization. Additionally, the developed nations have been recording slow growth as oppose to the developing and emerging countries participating in the value chain process. This has led to trade related disputes like Sino-USA trade wars, where both the countries have shown retaliation to their bilateral moves. However, trade issues like trade negotiations, trade wars, etc. needs strategical planning and understanding the viewpoint of the rival country. This can be perfectly captured and planned though various models used in game theory.

Game theory is the science of strategy or the optimal decision making of independent and competing actors in a strategic setting. It is considered to be a part of Microeconomics but it is widely used in various other economic fields like International Trade, Laboureconomics, Macroeconomics, Financial Economics, Behavioral Economics and many of the important policy issues have game theoretic character like negotiations over mutual reduction of tariffs, either bilaterally or under GATT, the international indebtedness and threatened default of some less developed countries, formation and preservation of custom unions, issues of International common property, establishment of cartels to raise the price of Internationally traded commodities, international implications of domestic macroeconomic policies, the possible international redistributions of income considered in the north south debate and the use of trade as a weapon in political warfare have game theoretic character. There is a strategic interdependence as what one agent's best action is depends upon what another agent does and vice versa.

Many trade economists have found game theoretic framework relevant for analyzing trade wars between two or more countries. Game theoretic tools like prisoner's dilemma, cooperative games, non-cooperative games, games with incomplete and imperfect information and many others have been used to draw economic and, sometimes, political implications from the game theory 
analysis of tariff and trade wars. This paper has been divided into three more sections, where the first section discusses about the implication of game theory models in the international trade. The following section confers about various references in the literature using game theory models in trade wars and trade negotiations. The last section bestows on the game theory models used for the U.S-A China trade war, followed by a conclusion.

\section{Game Theory models and its applications in International trade.}

\subsection{Tariff wars/Trade wars}

One of the defining attributes of the contemporary theory of trade wars is its explicit use of modern game theoretic tools in the analysis. A natural concept for modelling the outcome of a trade war is the non- cooperative nash equilibrium. In game theory, a combination of pure or mixed strategies $\mathrm{s} 1$ for agent $\mathrm{A} 1$, s2 for agent $\mathrm{A} 2, \ldots, \mathrm{sn}$ for agent An is a (non-cooperative) nash equilibrium combination if the strategies of the other agents are fixed and no single agent Ai could unilaterally increase the expected utility through mixed strategies by choosing a different pure or mixed strategy from among the strategies available. Considering a game where players are nations and strategies are choices of tariffs. The maximization of social welfare is a function of aggregate consumption quantities. Assuming that the world has only two country say, Australia and China, having comparative advantage and exporting good-1 and good-2 respectively. Assuming, the change in tariff rates does not affect the pattern of trade. Let Pc be the domestic price of good- 2 in china and Pc' be the good-2 price in foreign market. Similarly, $\mathrm{Pa}$ and $\mathrm{Pa}$ ' be the price of good-1 in Australia (domestic market) and foreign market, respectively. Both the countries impose import tax. Each country seeks to maximize its own utility function, which is a function of domestic prices, prices of other country and disposable income of the native country. In non-cooperative game of tariff setting, a Nash equilibrium would occur when each country set a tariff equal to the inverse of the elasticity of demand for its exports. (John McMillian, Game theory in international economics)

The analysis of tariffs in a perfectly competitive market demonstrates that if a large country imposes a relatively small tariff, or if it imposes an optimal tariff, then domestic national welfare will rise but foreign national welfare will fall (Reference). Suppose the Australia imports a set of products $(A, B, C$, etc.) from China, while China imports a different set of products $(X, Y, Z$, etc.) from Australia. Assuming that each country chooses two distinct trade policies, free trade and optimal tariffs. Each policy choice represents a game strategy. If Australia chooses 'Free Trade', then it imposes no tariffs on imports of goods $A, B, C$, etc. and if it chooses 'Optimal Tariffs', then it determines the optimal tariff in each import market and sets the tariff accordingly. China is assumed to have the same set of policy choices available

\begin{tabular}{|l|l|l|}
\hline \multicolumn{1}{|c|}{ Australia } & Free Trade & Optimal Tariffs \\
\hline Free Trade & 100,100 & 120,70 \\
\hline Optimal Tariffs & 70,120 & 90,90 \\
\hline
\end{tabular}

Fig (i): Payoff matrix when Australia and China fight a trade war

In fig(i) Australia's strategies are represented by the two columns; Chinese strategies correspond the two rows. The numbers represent the payoffs to the countries, measured as the level of national welfare. If China decides to impose optimal tariffs on all of its imports and Australia maintains its free trade position, then a partial equilibrium welfare analysis suggests the following:

1. Chinese welfare will rise (we'll assume from 100 to 120 units),

2. Australia's welfare will fall (we'll assume from 100 to 70 units) and

3. Global welfare will fall (i.e. the sum of Australian and Chinese welfare initially is 200 units, when both of them go for 'Free Trade' but falls to 120 $+70=190$ with China shifting to 'Optimal Tariff').

Since each country's actions raise its own welfare by 20 units and lower its trade partner's welfare by 30 units, when both countries impose tariffs, national welfare falls to 90 units in each country. To determine which strategy the two governments would choose in this game, we need to identify the objectives of the players and the degree of cooperation. Taking two different scenarios, one where each government is interested in maximizing its own national welfare and the governments do not cooperate with each other. and two, when the governments cooperate.A cooperative solution to a game is a set of strategies that would maximize the sum total of the benefits accruing to the players. In some instances, a cooperative outcome may require the transfer of goods or money between players to assure that each player is made better off than under alternative strategy choices. The cooperative solution in the trade policy game is the set of strategies (free trade, free trade). At this outcome, total world welfare is at a maximum of 200 units. 
A non-cooperative solution is a set of strategies such that each country maximizes its own national welfare subject to the strategy chosen by the other country. Thus, in general, if Australia strategy $(R)$ maximizes Australian welfare, when China chooses its strategy $(S)$ and if China's strategy $(S)$ maximizes China's welfare when the Australia chooses strategy $(R)$, then the strategy set $(R, S)$ is a noncooperative solution to the game. A non-cooperative solution is also commonly known as a nash equilibrium.

Assuming the existence of a Von Neumann type utility function for each country (Russia and the U.S.A) and countries set their tariff policies without any prior communication with each. Each country has two alternative strategies that are 'No tariff' $(\theta)$ and 'Optimal tariff' (T), given other country's tariff. Each country selects its tariff policy or strategy which maximizes its level of welfare.

\begin{tabular}{|c|c|c|}
\hline Russia & $\Theta$ & $\mathbf{T}$ \\
\hline$\Theta$ & $(\mathbf{a}, \mathbf{b})$ & $(\mathbf{c}, \mathbf{d})$ \\
\hline $\mathbf{T}$ & $(\mathbf{e}, \mathbf{f})$ & $(\mathbf{g}, \mathbf{h})$ \\
\hline
\end{tabular}

Fig (ii): Pay off matrix when two countries set tariffs in a non-cooperative framework

In fig (ii), if Russia chooses $\mathrm{T}$ and the USA chooses $\theta$ then the outcome is (c, d) which means that Russia receives $c$ and USA receives $\mathrm{d}$ which is measured in utility terms. So now according to the optimal tariff theorem (Reference) and if we start from free trade if one country charges a tariff and no retaliation takes place, the country which erects the tariff is better off and the other country is worse off. According to fig (iii), it means that $c>a, f>b, a>e$ and $\mathrm{b}>\mathrm{d}$. The outcome $(\mathrm{g}, \mathrm{h})$ is obtained when a tariff war occurs. So, according to Johnson's theorem (Reference), we know that there can be two possibilities. In the standard case, both countries are worse off than at free trade, $a>g$, $b>h$. The occurrence of Johnson's case will take place when one country benefits from a tariff war, implying $a>g$, $\mathrm{h}>\mathrm{b}$ or $\mathrm{g}>\mathrm{a}, \mathrm{b}>\mathrm{h}$. Compiling the optimal tariff theorem results and Johnson's tariff retaliation results, the standard case gives us that we have $c>a>g>e$ and $f>b>h>d$ and we get that both the countries loose from the tariff war. But in the Johnson case we have $c>g>a>e$ and $f>b>h>d$ implying that one country gains from the tariff war. Hence, when two countries play non-cooperatively, they will both chose the strategy of charging the optimal tariff and free trade will not be reached.
Using the same approach as Rosendorff and Milner (2001), where two countries play a tariff setting game in an infinitely repeated Prisoner's dilemma tariff setting (a two-stage game). When the two countries do not cooperate, countries apply their respective optimal tariffs vis-a-vis each other and hence are stuck in a sub optimal nash equilibrium. In this kind of a setting, if there is a strong punishment against the deviator only then the cooperation can be achieved and sustained. If the shocks that influence the incentive to deviate from cooperation occur are strong, then cooperation will break down.

2.1.1 Tariff setting model using infinitely repeated prisoner's dilemma game

It is a two-country world where each country exports one good to the other, but these two countries are symmetric in every other sphere. Every country's payoff function is a function of its own tariff $\mathrm{T}$ and Foreign Tariff $\mathrm{T}^{*}$ i.e. $\mathrm{U}=$ $\left(\mathrm{T}, \mathrm{T}^{*}\right)$. There is a best response function that exists, producing the most favourable outcome for a player, taking other player's strategies as given. The game theoretic approach of infinitely repeated prisoner dilemma can be used of modelling of trade policy with regard to tariff setting between two countries that can chose between cooperation or deviation. This consists of two stages. In the first stage, both countries chose a level of cooperative tariff denoted by $\mathrm{T}_{\mathrm{CO}}$ from a continuum and agree on how the deviations should be punished. In the second stage, the infinitely repeated prisoner's dilemma game is played. When the game starts, each country will have to choose between implementing the agreed cooperative tariff and applying the optimal tariff $\mathrm{T}_{\mathrm{DE}}=\mathrm{T}_{\mathrm{BR}}\left(\mathrm{T}_{\mathrm{CO}}\right)$ vis a vis the other country.

However, setting a tariff different from $\mathrm{T}_{\mathrm{CO}}$ is regarded as a deviation, then a country's choice is considered to be binary, that is, they have two choice of tariff $-\mathrm{T}_{\mathrm{CO}}$ and $\mathrm{T}_{\mathrm{DE}}$. The per period payoff under perfect symmetry is given by $\mathrm{U}_{\mathrm{CO}}=\mathrm{U}\left(\mathrm{T}_{\mathrm{CO}}, \mathrm{T}_{\mathrm{CO}}\right)$. If any country breaks its commitment and apply the optimum tariff vis-a-vis its trading partner gets the payoff as $\mathrm{U}_{\mathrm{DE}}=\mathrm{U}\left(\mathrm{T}_{\mathrm{DE}}, \mathrm{T}_{\mathrm{CO}}\right)$, implying that the country's trading partner will receive a sucker's payoff (footnote1) $\left(\mathrm{U}_{\mathrm{S}}=\mathrm{U}\left(\mathrm{T}_{\mathrm{CO}}, \mathrm{T}_{\mathrm{DE}}\right)\right.$. When none of the countries cooperate, both the countries apply optimal tariff vis-a-vis each other. Here Nash tariff is denoted by $\mathrm{T}_{\mathrm{N}}=\mathrm{T}_{\mathrm{BR}}\left(\mathrm{T}_{\mathrm{BR}}\right)$ and both the countries receive payoff of $U_{N}=W\left(T_{N}, T_{N}\right)$. The cooperative level $T_{C}$ that has been chosen directly defines the payoff under cooperation $\mathrm{U}_{\mathrm{CO}}$ and also indirectly via the best response function, defines payoffs of deviation $\mathrm{U}_{\mathrm{DE}}$ and being deviated against $U_{S}$. There exists unique level of tariff. 


\begin{tabular}{|l||l|l|}
\hline Country 1 & Cooperate & Deviate \\
\hline Cooperate & $\mathrm{U}_{\mathrm{C}, \mathrm{U}_{\mathrm{C}}}$ & $\mathrm{U}_{\mathrm{S}}, \mathrm{U}_{\mathrm{D}}$ \\
\hline Deviate & $\mathrm{U}_{\mathrm{D}}, \mathrm{U}_{\mathrm{S}}$ & $\mathrm{U}_{\mathrm{N}}, \mathrm{U}_{\mathrm{N}}$ \\
\hline
\end{tabular}

Fig (iii): Payoff matrix in an infinitely repeated prisoner's dilemma game

If the countries stick to the grim trigger strategy Note-1) and it deviates, it will be punished by infinite reversion to the Nash equilibrium. Cooperation is sustainable, if and only if the cost of deviation outweighs the one period gain from deviating i.e.,

, $\mathrm{U}_{\mathrm{D}}-\mathrm{U}_{\mathrm{C}} \leq \alpha / 1-\alpha\left[\mathrm{U}_{\mathrm{C}}-\mathrm{U}_{\mathrm{N}}\right]$

where $\alpha$ is the discount factor. Short term gain from deviation (one period) is shown on the left side and the right-hand side represents the expected long-term loss from deviation. Rearrange the terms of equation (1), we get

, $\mathrm{U}_{\mathrm{D}}-\mathrm{U}_{\mathrm{C}} / \mathrm{U}_{\mathrm{C}}-\mathrm{U}_{\mathrm{N}}=\alpha / 1-\alpha$

which implies that to sustain cooperation, $\mathrm{T}_{\mathrm{C}}$ can be lowered to the degree that $\mathrm{U}_{\mathrm{D}}-\mathrm{U}_{\mathrm{C}} / \mathrm{U}_{\mathrm{C}}-\mathrm{U}_{\mathrm{N}}$ does not exceed the upper bound, which is solely determined by the discount factor and increases monotonously in $\mathrm{U}_{\mathrm{D}^{-}} \mathrm{U}_{\mathrm{C}} / \mathrm{U}_{\mathrm{C}^{-}}$ $\mathrm{U}_{\mathrm{N}}$.Since $\alpha \in(0,1)$ and thus $\alpha / 1-\alpha \in(0, \infty)$ and it is always possible to find a tariff level which satisfies $\mathrm{T}_{\mathrm{C}}<\mathrm{T}_{\mathrm{N}}$ which will be sustainable. If the discount factor is high, it implies that the upper bound increases, and ${ }^{1}$ it is possible to sustain a lower $\mathrm{T}_{\mathrm{C}}$. Therefore, the optimal cooperative tariff is sustainable for a sufficiently high discount factor.

\subsection{Trade Negotiations}

A game theoretic framework can also help in analyzing the outcomes of trade negotiations between two countries and can answer questions like - what will be the effect of the strategies played by each country and how can each country maximize its own welfare from the trade negotiation. Additionally, it also helps to analyse the dispute settlement system and helps to find out what is the optimal strategies that each country can play to win in this dispute settlement.

\footnotetext{
${ }^{1}$ (Sucker payoff is the payoff when a player always cooperated regardless of whether the other player is cooperating or not, the payoff that will be the received by the player who always cooperates is called the Sucker's payoff)
}

\subsubsection{Negotiations as Imperfect Game}

WTO negotiations can be seen as a dynamic game, especially a sequential game where players play their strategies in a sequence which are successive in time and is with incomplete information, in the sense that one player does not know one or more of the wining functions of the other player. This is also known as Bayesian Game. However, to define a perfect Bayesian Equilibrium, we will first define what is a Bayesian Nash Equilibrium. It is an equilibrium which can result in implausible equilibrium in dynamic games in which players move sequentially rather than simultaneously (Reference). This can arise because of the result of non-credible strategies off the equilibrium path. Assumption required for the game are information is non-unique information, player's strategies are sequentially rational, assumptions are determined by Bayes Rule when information is on path of balance, if information is outside the equilibrium path it may also be decided by Bayes rule and player's balance strategies if that is possible. We define on and off equilibrium paths as

For a given equilibrium in a given extensive form game, an information set is on-the-equilibrium path, if it is reached with positive probabilityand the game is played according to equilibrium strategies and if it is certain not to reached to the equilibrium while playing the equilibrium strategies then the information set is on the off-theequilibrium-path

So, a Bayesian perfect balance is a lot of strategies and assumptions that are satisfied. A player has three choices of action which are S- Support for agriculture, B-Use of Barriers and R- Give up. If a player chooses action R then the game ends without player 2 choosing his own action. If player 1 choses either $\mathrm{S}$ or $\mathrm{B}$ then player 2 learns that $\mathrm{R}$ has not been chosen (but not S or B was chosen) and then choses between two actions $\mathrm{S}$ and $\mathrm{R}$ after which the game ends.

\begin{tabular}{|l|l|l|}
\hline \multicolumn{1}{|c|}{ Player-1 } & S” & R" \\
\hline B & Player -2 & \\
\hline S & $2,1^{*}$ & $-1,0$ \\
\hline R & $3^{*}, 1^{*}$ & $-2,0$ \\
\hline
\end{tabular}

Fig (iv) Payoff matrix of Imperfect game 
We have drawn the normal form representation of this game and we can see that we have

The normal form game provides two pure Nash Equilibrium which are (S, S') and (R,R") strategies. The table implies that (R, R') clearly depends on an unreasonable threat that if player- 2 makes a choice then the choice $\mathrm{S}$ " takes precedence over the choice of R", therefore, player-1 must not choose R but R".

\subsubsection{Negotiations as Theory of Moves}

A branch of game theory of moves was proposed by Brams (Year) and is used to model the negotiations on agriculture during the Uruguay round of WTO. We are going to take our model of this negotiation process given by author Ewa Kiryluk-Dryjska (Year). The extensive form and normal form of the classical game theory gets combined in theory of moves. Players move from one outcome in a payoff matrix to another because of which the sequential moves of an extensive form game are built into the normal form. To achieve that normal form game is transformed into a dynamic one using backward induction. The Theory of Moves (TOM) help in embedding extensive form calculations within the normal form, deriving advantages of both forms. The main attribute of this theory is that it allows for the possibility that player's plans may be revised as they are being carried out.

The changing strategic nature of the game is captured as they evolve over time since TOM allows player, starting at any outcome in a payoff matrix, to move and countermove within the matrix. The game is different when play starts in a different state, but the payoff matrix remains unchanged. Players can make a rational calculation of the advantages of staying or moving. They move precisely because they anticipate a better outcome when the movecountermove process finally comes to rest. There are certain rules for theory of moves like players can unilaterally switch their strategy, game terminates in a final state and outcome will be induced by the player who moves first. Each state has an outcome which is called "non myopic equilibrium". It is the consequence of both players looking ahead and anticipating where from each of its initial states, the move countermove process will culminate.

In the beginning of the Uruguay Round, the U.S.A was engaged in food export subsidy war with the Economic Union (EU). Due to the implementation of Common
Agriculture Policy (CAP), there was a significant reduction of the U.S.A agricultural exports to the EU. The negotiations became tense due to the long term oilseeds products conflict, which started in 1988 when the U.S.A challenged the aid provided by the EU before the GATT panel. These escalating agricultural disputes led the U.S.A to consider trade sanctions on the EU. The pay off matrix of the game is given in the below figure (v), representing strategies and outcomes for the U.S.A and the EU before the start of Uruguay Round for agricultural negotiations. Here, the nash equilibrium is $(2,2)$ and the non-myopic equilibrium is $(3,4)$.

\begin{tabular}{|l|l|l|}
\hline & Sanctions & No Sanctions \\
\hline Reforms & $(1,3)$ & \\
\hline No reforms & $(2,2)^{*}$ & $(3,4)^{\mathrm{MME}}$ \\
\hline & & $(4,1)$ \\
\hline
\end{tabular}

Fig (v): Payoff matrix of negotiations between USA and EU.

The best option for the EU would be to avoid both reforms and the U.S.A sanctions as their internal circumstances forced them to minimize policy changes and consequently defend the current shape of the CAP (Daugbjerg,2007). Reforms with no sanctions would have been the second best option for the EU. The worst option for the EU was to conduct reforms and still remain under pressure from the USA. The best option for the USA was that the EU to implement CAP reform and thereby avoiding the need for sanctions. The second best options for USA was reforms with sanctions. The worst case scenario for the USA would have been - no reforms and no sanctions.

In the standard game theory $(2,2)$ is being predicted as the outcome the unique pareto inferior Nash Equilibrium. This is the product of the EU's dominant strategy of no reforms and the USA's best response given EC's dominant choice of Sanctions. According to TOM, the choice of the unique Non-Myopic equilibrium of $(3,4)$ is pareto superior to $(2,2)$. Now we will see this solution using the backward induction technique

Progression of moves using backward induction. 
EC starts as survivor.

EC $\mathrm{R}$

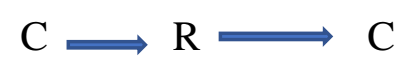
$(4,1)$
$(3,4)$
$(1,3)$
$(2,2)$
$(4,1)$
$(3,4)$

$(4,1)$

US starts as survivor

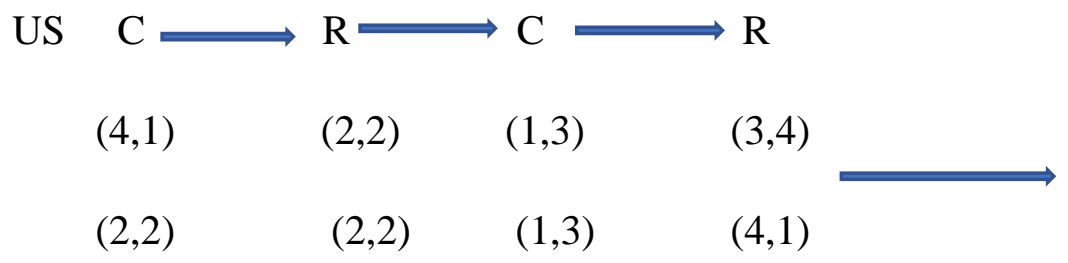

When the EC starts, there is a blockage at the outset at $(4,1)$ whereas as the USA starts it moves to $(2,2)$ where play stops. The USA's rational choice of moving to $(2,2)$ takes precedence over the EC's rational choice of staying at $(4,1)$. It implies that TOM would predict $(2,2)$ outcome which would also be the anticipated result in standard game theory. However, according to 'Two Sidedness Convention', (Footnote -2)

TOM provides a realistic model of sanctions since several preferred configurations have NME in which sanctions lead to compliance.

Another way of interpreting the deadlock state can be through the use of the concept Deterrent Threat Power (Reference, Year). This power enables a player, having a threat power, to threaten the other player with a mutually disadvantageous outcome in order to deter certain moves in the future play of the game. Here, the EC is an advantaged player whereas the USA is called a frustrated player (Brams, XXXX). The EC has a dominant strategy that can inflict two worst outcomes on the frustrated player. Deterrent threat can be used by the USA to escape from worst outcomes, as in the game USA has the deterrent power. If we start from $(4,1)$ it can threaten to choses sanctions leading to the breakdown of the outcome $(2,2)$, if the threat is carried out. If pareto inferior outcomes is to be avoided, then it is in both players interest that the US should induce threat power $(3,4)$ rather than suffer the breakdown outcome, hence outcome (NME) would be $(3,4)$.

2.3 Trade Policy (using Brander Spencer model)

${ }^{2}$ If one player (say Column) by moving, can induce a better state for itself than by staying- but second player (say Row) by moving can induce a state Pareto-superior to Column's induced
Export subsidies play an important role in international trade policy. In western economies there has been a practice of effective subsidization for firms engaged in international rivalry (Reference, XXXX). Its effectiveness to gain an advantage is undeniable when rival countries do nothing, if the other countries use a subsidy policy as well, however both firms would be better off if neither of them used subsidy. The following game by Krugman (Year) would provide a detailed analysis for such a case, where the model is as follows:

There are two firms Boeing (American) and Airbus (European), in the business of airline manufacturing. Now, Indian market opens up for both the firms and they both are keen to enter the market and export their product, assuming if only one firm enters in the market, it will make a profit but if both try to enter then both incur loss.

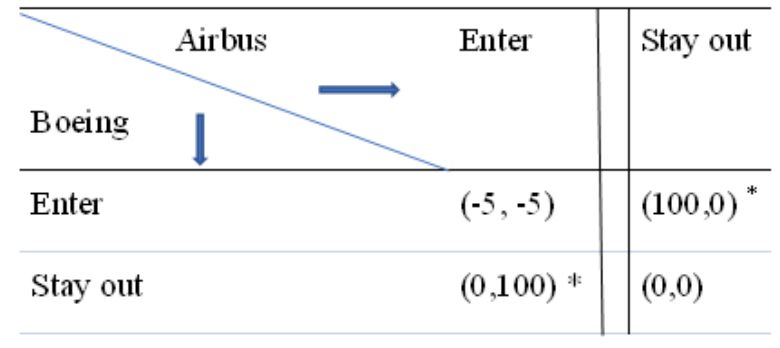

Fig (vi): Payoff of Airbus and Boeing without subsidy

There are two strategies for both firms - enter or stay out. There are two Nash Equilibrium in this matrix which are $(0,100)$ and $(100,0)$, implying that if only one firm enters then it will earn huge profits and the other firm will earn zero and if both enter, then both will incur loss and if both

sate - then Row will move, even if it otherwise would prefer to stay, to effect better outcome 
stay out, no one earns anything. Assuming that the EU gives subsidy of 25 .

\begin{tabular}{|l|l|l|}
\hline Boeing & Enter & Stay out \\
\hline Enter & $(-5,20)$ & $(100,0)$ \\
\hline Stay out & $(0,125)^{*}$ & $(0,0)$ \\
\hline
\end{tabular}

Fig (vii): Payoff of Airbus and Boeing with subsidy

In the new payoff matrix, since the EU gave subsidy to Airbus, the profits has risen where both firms enter the market. If Boeing stays out of the market, then Airbus will earn an additional profit of 25, with the Nash Equilibrium (Stay out, Enter) with payoffs $(0,125)$. Therefore, if a government subsidizes its domestic firm for competing against international firms, the domestic tends to gain and the international firms tend to lose.

\section{REVIEW OF LITERATURE}

There are various evidences in the literature showcasing the use of game theoretical models in policy planning for international trade. One among them is Iona (2008) where the paper discusses a choice for a country's foreign policy between free trade policy or a protectionist trade policy. The paper takes into consideration two countries - the United States and Japan and two strategies — 'Free Trade' and 'Protection', where if both choose 'Free Trade', then both gain and if both chose 'Protection' then there is no gain and if one chose 'Protection' and other one 'Free Trade' then the one who chose 'Protection' will gain. So we can say that given the payoffs the optimal strategy for both countries could be free trade or both could chose protection. In the next two games, the author introduces industrial subsidy and government subsidy, consecutively, with two players are Boeing and Airbus. This is also a part of Brander Spencer model. The outcome is that the firm that gets a subsidy from its home country tend to earn more profits than the firm which does not get and they are at loss.

The trade wars of the United States and China has been the talk of the town in the recently. Yin and Hamilton (2008) represents the strategies and the outcome of that strategies implemented by the U.S.A and China during their trade war. This was further persuaded by Namaki (2008) which uses sequential chicken game constituting a simultaneous and non-cooperative game where if one person deflects, that person loses the game or the pride of victory and if they both don't deflect, they will class head on. MccGwire (2017) develops a strategic form game where nash equilibrium resulted with both countries implementing 'Tariff' as their best strategy, even though playing 'Free Trade' strategy for both the countries would have yield better outcomes. Analyzing the welfare effects of the strategies, the paper concludes playing 'Trade' strategy by both the countries would result in a prosperous trading environment, while imposition of tariffs would result in rapid decline in the global trade, GDP and welfare of the countries.

Harrison and Rutstrom (1991) describes a general game theoretic model using actual empirical data and showing a game between EU and the USA, with evaluating the cost of protection using a global general equilibrium model with $\mathrm{n}$ person negotiations. The uses a cooperative negotiation situation in terms of bargaining environment and a bargaining process. Applying the concept to a trilateral war between US, EU and Japan the author assumes that payoffs to each nation are the changes in welfare of the consumers of the country. The author took empirical data and used it in modelling of game theory where he assumed that EU, USA and Japan will apply tariffs with different amounts and there will be variations in the effects of increase tariff by these three countries. Different situations have been assumed and the paper concludes that the increased tariff in these trilateral war affects the global economy and sometimes developed countries gets more affected than developing countries, using non-cooperative trade wars and cooperative trade negotiations.

A redistribution model (Abbot and Kallio,1996) for the imperfect market of International Trade incorporating different level of export subsidies, net exports and political payoffs for four regions (or players): USA, EU, CAIRNS and importers. There has been a perfect analysis of Nash equilibrium and using GATT outcomes and seeing how the export subsidies react when being imposed with constraints or without constraints and is it feasible to make a cartel or cooperating without making a cartel. It has been successfully showed that the policy problem of large exporters in a prisoner's dilemma game where GATT has been viewed as an institution which can alter the market outcome and move it towards a cooperative equilibrium solution where free trade or the elimination of export subsidies should be the only solution if all trading countries cooperate and he has shown it by taking the applied examples of EU and USA.

Grossman and Helpman (1993) created a framework of game theoretical setting where they studied noncooperative and cooperative trade policy games in a setting where domestic politics determine international objectives. 
The framework for the game allows the incumbent government to set nation's trade policies either unilaterally or in conjunction with other governments through international organizations. The government has the right to choose a schedule of trade taxes and subsidies on the various import and export goods. The government enters the international arena considering interests of lobby groups for maximising their welfare. As a resultant of the game, the country reaches an equilibrium schedule of trade taxes and subsidies for each country as well as a set of political contributions by various stakeholders to ensure a political equilibrium. Additionally, it was also found that certain industry groups having a strong political backing has major influence on the government for tariff cuts or reductions in national policy.

\section{USA-CHINA TRADE WAR CASE STUDY}

In 2017 when the USA trade commission expressed concerns that imports of washing machines and solar panels from China damaged its industries, the SinoAmerican trade dispute escalated in 2018 and both the countries found themselves in a web of never-ending threats, which have a significant negative impact on their economies. The U.S.A manufacturing sector suffered because the price of intermediate inputs had gone up. Moreover, China retaliated with their own tariff, making harder for the U.S.A manufacturing companies to sell in the Chinese market. A negative impact that this trade war has created is on the global CAPEX spending as a lot of multinational companies in the USA had slowed down their CAPEX spending because of a lot of uncertainty. The cost of increase in tariffs are being borne by American producers, instead of China, for mainly two reasons. One, Chinese exporters have not reduced their U.S.A dollar border prices and two, the U.S.A importer or retailers decided to not to pass the additional cost to the U.S consumers (reference, XXXX). The U.S exports to China dropped by nearly 30 billion dollars while imports from China fell by over 70 billion dollars, with reduction in investment, production and Gross domestic product growth.

The effects of trade war between the two largest countries not only hurts their economies, but in the age of globalization and integration can impact global growth and dampen the growth of many major emerging economies. In November 2019, by a recent estimate (Bank of Finland, Year), tariff increase due to Sino-American trade war could slow down the global GDP growth by $0.7 \%$ points, with a costing 585 billion dollars by 2021 . The uncertainty over trade could lower the world GDP by $0.6 \%$ in 2021 as compared to a no trade war scenario. OECD estimated that the world GDP growth will fall from $3.5 \%$ to $3.2 \%$ and it will increase just $0.2 \%$ in the next year with highlighting that trade tensions are the principal factor threatening the global economy

3.1 Game Theoretic Models for analyzing Sino-American Trade War

Model -1: Sequential chicken game (or Snowdrift Game)

\begin{tabular}{|c|c|c|c|c|}
\hline China & Cooperate & \multicolumn{3}{|l|}{ Defect } \\
\hline Cooperate & $(4,4)$ & \multicolumn{3}{|l|}{$(0,3)$} \\
\hline \multirow[t]{3}{*}{ Defect } & \multirow[t]{3}{*}{$(3,0)$} & Us & Turn & Stay \\
\hline & & Turn & $(0,0)$ & $(-1,1)$ \\
\hline & & Stay & $(1,-1)$ & $(-10,-10)$ \\
\hline
\end{tabular}

\section{Fig (viii): Payoff matrix of USA and China engaged in a} sequential chicken game

Fig (viii) demonstrates a modified prisoner's dilemma matrix, with a chicken game matrix as a subgame in the event of mutual defection outcome. A chicken game matrix is a two-player simultaneous, non-cooperative and has two strategy choices Stay or Turn. To avoid the problems when instances of mutual defection occur, the game gets shifted to a chicken game, which represents the dilemma of trade war between both parties. In this game, the pure strategy Nash Equilibrium are asymmetric outcomes for each player which is absent in prisoner's dilemma, This allows for a model inducement since the stay strategy is the only winning strategy, and a player must believe that the other player will commit to the turn strategy and make it a risk mutual destruction. The probability that the other will turn instead of stay, if that has to be increased, that requires signaling of intent and greater leverage.

Model -2

In the new model there are two types of Chinese governments, one which is aggressive and the other tactical. The aggressive Chinese government will retaliate equally to any tariff placed on Chinese goods without considering the consequences. The tactical Chinese government would fully understands the extent to which its economy is reliant on export-led growth and the consequence of decline in exports. Assuming that the tactical Chinese government can manipulate the currency in a way such that an increase in tariffs by the USA does not result in a zero payoff if China opts for free trade. The 
currency devaluation allows China to receive a higher payoff than the USA if both opt for free trade. The other assumption is that China will be opportunistic and will seek a trade deal that the USA turns away from. This will help China in increasing its payoff. The model also assumes that both China and the USA will be worse off if they both impose tariffs. In the extensive form representation, (see fig ix), the payoffs the USA receives vary, depending on whether they interact with the aggressive or tactical China. Since the USA does not know that with which type of Chinese government they are dealing with, there are probabilities that have been assigned to calculate the payoffs. The probability that China is aggressive is 0.4 and tactical is 0.6. These are determined by Nature which moves first in the game.

Nature

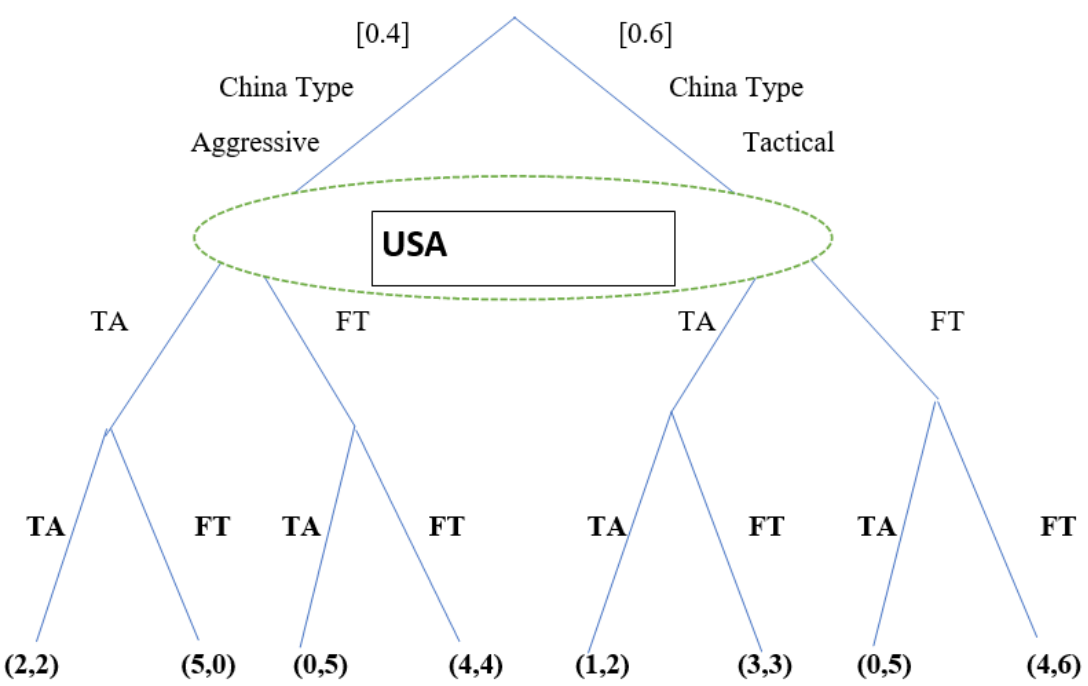

Fig (ix) : Extensive Form Representation
China's optimum strategy for all subgames is (TA, TA, FT,FT). The USA being aware of it calculates their expected payoffs given these strategies. The USA's expected payoffs for choosing tariff are 2.6 and for the free trade it is 2.4 , implying that they will opt to impose tariffs providing a Nash equilibrium at (TA, TATAFTFT) .

\section{CONCLUSION}

Economists have tried to explain through game theory whether to liberalize or use protectionist measures. Tariff setting is an important part for any country's trade policy and game theory helps us to find that level of tariff that will have help a country to generate the maximum amount of welfare with respect to the other country's tariff. Different game theory methods shown in the paper and many more are used for developing the optimum level of tariff to get the maximum welfare. Game theoretical methods helps us to analyze the best strategy when two countries are negotiating. When countries get involved in a trade war there is trade retaliation and it is not that only the governments fight between themselves but it puts a pressure on all the stakeholders that do get impacted by the trade policy and especially the multinational firms. Many of the U.S.A companies are moving out of the China and are being subsidized or being given grants to shift the manufacturing base due to the trade war between the United States and China. Moreover, companies like Huawei which are facing a severe criticism from the U.S.A Government and is pressurizing its allies to ban Huawei from their countries or the $5 \mathrm{G}$ trials. Brander Spencer model which through the help of simple prisoner's dilemma helps to analyze the strategic behavior when two companies are involved in a battle.

\section{ACKNOWLEDGEMENTS}

This paper was written as a part of Internship at Research and Information System for Developing Countries, a policy think tank under Mimistry of External Affairs , Government of India.I would like to thank Prof. S.K. Mohanty and Assistant Professor Dr. Pankhuri Gaur for their guidance and support in writing this research paper.

\section{REFERENCES}

[1] Abbott, P. C. (1996). Implications of game theory for international agricultural trade. American Journal of Agricultural Economics, 78(3), 738-744.

[2] Alexa, I. V., \& Toma, S. V. (2012). The Correlation between Game Theory and International Trade. 
[3] Bagwell, K., \& Staiger, R. W. (1988). A theory of managed trade (No. w2756). National Bureau of Economic Research.

[4] Bagwell, K., Staiger, R. W., \& Yurukoglu, A. (2017). "Nash-in-Nash" Tariff Bargaining with and without MFN (No. w23894). National Bureau of Economic Research.

[5] Bekkers, E., Francois, J., Nelson, D. R., \& RojasRomagosa, H. (2019). Trade Wars and Trade Disputes: The Role of Equity and Political Support. Working Paper, World Trade Institute.

[6] Bekkers, E., Francois, J., Nelson, D. R., \& RojasRomagosa, H. (2019). Trade Wars and Trade Disputes: The Role of Equity and Political Support. Working Paper, World Trade Institute.

[7] .Brams, S. J. (2003). Negotiation Games: Applying game theory to bargaining and arbitration (Vol. 2). Psychology Press.

[8] Brams, S. J., \& Hessel, M. P. (1984). Threat power in sequential games. International Studies Quarterly, 28(1), 23-44.

[9] Brams, S. J., \& Hessel, M. P. (1984). Threat power in sequential games. International Studies Quarterly, 28(1), 23-44.

[10] Brandenburger, A., \& Nalebuff, B. J. (2009). Right Game: Use Game Theory to Shape Strategy. Harvard Business Review Press.

[11]Brander, J. A. (1995). Strategic trade policy. Handbook of international economics, 3, 1395-1455.

[12] Brander, J. A., \& Spencer, B. J. (1984). Trade warfare: tariffs and cartels. Journal of international Economics, 16(3-4), 227-242.

[13] Coddington, A. (1967). Game Th Eory, Bargaining Th Eory, and Strategic Reasoning. Journal of Peace Research, 4(1), 39-44.

[14] Copeland, B. R. (1990). Strategic interaction among nations: negotiable and non-negotiable trade barriers. canadian Journal of Economics, 84-108.

[15] Demertzis, M., \& Fredriksson, G. (2018). The EU Response to US Trade Tariffs. Intereconomics, 53(5), 260-268.

[16] Devarajan, S., Go, D. S., Lakatos, C., Robinson, S., \& Thierfelder, K. (2018). Traders' Dilemma: Developing Countries' Response to Trade Disputes. The World Bank

[17]Dobre, C. (2008). Implication of game theory to international trade. Revista tinerilor economişti, (10), 132-137.

[18] Dorsey, J. M. (2019). Trump's Trade Wars: A New World Order?.
[19]El Namaki, M. S. S. (2018). Trump, Xi and Game Theory. Scholedge International Journal of Business Policy \& Governance, 5(5), 1-6.

[20]Felbermayr, G., \& Steininger, M. (2019). Trump's trade attack on China-who laughs last? (No. 13). EconPol Policy Brief.

[21]Feng, L., Liu, L., \& Zhang, H. (2019). Game TheoryBased Pathway Selection for Fair and Reciprocal Cooperation among Ports along the Maritime Silk Road. Mathematical Problems in Engineering, 2019.

[22] Fudenberg, D., \& Levine, D. K. (2016). Whither game theory? Towards a theory of learning in games. Journal of Economic Perspectives, 30(4), 15170.

[23] Gibbons, R. (1997). An introduction to applicable game theory. Journal of Economic Perspectives, 11(1), 127-149.

[24] Gould, D. M., \& Woodbridge, G. L. (1998). The political economy of retaliation, liberalization and trade wars. European Journal of Political Economy, 14(1), 115-137.

[25] Grossman, G. M. (2016). The purpose of trade agreements. In Handbook of commercial policy (Vol. 1, pp. 379-434). North-Holland.

[26] Grossman, G. M., \& Helpman, E. (1995). Trade wars and trade talks. Journal of political Economy, 103(4), 675-708.

[27] Harrison, G. W., \& Rutström, E. E. (1991). Trade wars, trade negotiations and applied game theory. The Economic Journal, 101(406), 420-435.

[28]Herzing, M. A Prisoner's Dilemma Tariff Setting Game with an Escape Clause.

[29] Horn, H., \& Mavroidis, P. C. (2006). A survey of the literature on the WTO dispute settlement system.

[30] Hughes, R. (2007). A "Modified Prisoners' Dilemma" Approach to Progress in the World Trade Organization's Agricultural Trade Negotiations. Issues in Political Economy, 16, 1-20.

[31] Kiryluk-Dryjska, E. (2016). Negotiation analysis using the theory of moves-Theoretical background and a case study. Journal of Policy Modeling, 38(1), 44-53.

[32] Lackman, C. (2012). EU-ASEAN: Trade Policy: A Game Theory View. Journal of Global Business Management, 8(2), 1.

[33] Li, C., \& Whalley, J. (2020). Trade protectionism and US manufacturing employment. Economic Modelling.

[34] Li, C., He, C., \& Lin, C. (2018). Economic impacts of the possible China-US trade war. Emerging Markets Finance and Trade, 54(7), 1557-1577. 
[35]Li, M., Balistreri, E. J., \& Zhang, W. (2018). The 2018 trade war: Data and nascent general equilibrium analysis.

[36]Liu, T., \& Woo, W. T. (2018). Understanding the USChina trade war. China Economic Journal,11(3), 319-340.

[37]Lohmann, S., \& O'halloran, S. (1994). Divided government and US trade policy: theory and evidence. International organization, 595-632.

[38] Maggi, G. (1999). Strategic trade policy under incomplete information. International Economic Review, 40(3), 571-594.

[39] Mann, C. L. (1987). Protection and Retaliation: Changing the'Rules of the Game'. Brookings Papers on Economic Activity, 1987(1), 311-335.

[40] Martin, A., \& Vergote, W. (2008). On the role of retaliation in trade agreements. Journal of International Economics, 76(1), 61-77.

[41] Mayer, W. (1981). Theoretical considerations on negotiated tariff adjustments. Oxford Economic Papers, 33(1), 135-153.

[42] MccGwire, J. (2018). A Game Theory Analysis of Donald Trump's Proposed Tariff on Chinese Exports. Stud. Econ. Rev, 31, 69-77.

[43] McMillan, J. (1989). A Game-theoretic view of international trade negotiations: implications for the developing countries. In Developing countries and the global trading system (pp. 26-44). Palgrave Macmillan, London.

[44] Mehdi, R. (2008). The sustainable cooperative tariffs: a political economy perspective.

[45] Mock, W. B. (1992). Game Theory, Signalling, and International Legal Relations. Geo. Wash. J. Int'l L. \& Econ., 26, 33.

[46] Nelson, W. R. (2001). Incorporating fairness into game theory and economics: Comment. American Economic Review, 91(4), 1180-1183.

[47] Ossa, R. (2011). A "new trade" theory of GATT/WTO negotiations. Journal of Political Economy, 119(1), 122-152.

[48] Ossa, R. (2014). Trade wars and trade talks with data. American Economic Review, 104(12), 4104-46.

[49] Özyildirim, S. (1996). Three-country trade relations: A discrete dynamic game approach. Computers \& Mathematics with Applications, 32(5), 43-56.

[50] Robinson, S., \& Thierfelder, K. (2019). US-China Trade War: Both Countries Lose, World Markets Adjust, Others Gain (No. PB19-17).

[51] Steinbock, D. (2018). US-China Trade War and Its Global Impacts. China Quarterly of International Strategic Studies, 4(04), 515-542.
[52] Urata, S. (2020). US-Japan trade frictions: The past, the present, and implications for the US-China trade war. Asian Economic Policy Review, 15(1), 141-159.

[53] Vanzetti, D. (1996). The next round: game theory and public choice perspectives. Food Policy, 21(4-5), 461477.

[54] Winchester, Niven. "A classroom tariff-setting game." The Journal of Economic Education 37, no. 4 (2006): 431-441.

[55] Yin, J. Z., \& Hamilton, M. H. (2018). The Conundrum of US-China Trade Relations Through Game Theory Modelling. Journal of Applied Business and Economics, 20(8).

[56]Zhang, Y. (2018). The US-China Trade War. Indian Journal of Asian Affairs, 31(1/2), 53-74. 